\title{
EKSISTENSI RUANG VEKTOR ATAS LAPANGAN TERHADAP MODUL BEBAS
}

\author{
Chrisanty Y. Tambayong ${ }^{1)}$, Jullia Titaley ${ }^{1)}$, Rinancy Tumilaar ${ }^{1)}$ \\ Program Studi Matematika, Fakultas MIPA, Universitas Sam Ratulangi \\ email : chrisantytambayong28@gmail.com; july_titaley@yahoo.com; \\ rinancytumilaar@gmail.com;
}

\begin{abstract}
ABSTRAK
Modul merupakan perluasan dari ruang vektor. Suatu Ruang vektor $V$ atas lapangan $F$ merupakan suatu himpunan vektor - vektor dengan dua operasi yaitu penjumlahan dan perkalian dengan skalar. Sebarang ruang vektor $V$ atas lapangan $F$ dapat dipandang sebagai modul atas ring $F$. Tetapi tidak semua modul dapat dinyatakan sebagai ruang vektor atas lapangan. Tujuan penelitian ini adalah untuk memberikan counter example bahwa tidak semua modul merupakan ruang vektor atas lapangan. Dari hasil penelitian dapat disimpulkan bahwa setiap modul yang memiliki basis merupakan ruag vektor atas lapangan adalah modul bebas.
\end{abstract}

Kata kunci : Ruang vektor, modul, dan modul bebas

\section{THE EXISTENCE OF VECTOR SPACE OVER A FIELD OF FREE MODULE}

\begin{abstract}
Module is an extension of a vector space. A vector space over a field is a set of vectors with two binary operation. The binary operation is addition and scalar multiplication. A vector space is a module over a field, many of basic concepts that we defined for vector space can also be defined module. But it's not all module vector space over a field. The purpose of this tesis is for give counter example that it's not all module vector space over a field. From the result of this research show that a module have bases is vector space over a field is free module.
\end{abstract}

Keywords : vector space, module, free module

\section{PENDAHULUAN}

Ruang vektor merupakan struktur matematika yang terbentuk oleh sekumpulan vektor dengan dua operasi yaitu penjumlahan dan perkalian skalar serta memenuhi beberapa aksioma.

Sedangkan, Ruang vektor atas lapangan adalah suatu himpunan tak kosong dari elemen-elemen yang merupakan vektor bersama dengan dua operasi yaitu penjumlahan dan perkalian skalar, yang dimana skalar merupakan unsur dari lapangan.

Modul merupakan struktur aljabar yang dikembangkan dalam dua himpunan yang tidak kosong dan memenuhi syarat tertentu yaitu distributif kanan, distributif kiri, dan mempunyai elemen identitas. Suatu modul yang memiliki basis disebut modul bebas. Basis merupakan bagian dari ruang vektor atas lapangan yang memenuhi syarat yaitu bebas linier dan merentang. Berdasarkan hal-hal yang telah diketahui bahwa semua Ruang vektor atas lapangan merupakan suatu modul bebas tetapi belum tentu semua modul merupakan suatu ruang vektor atas lapangan. Oleh karena itu, penelitian ini bertujuan untuk mengkaji tentang modul bebas yang merupakan suatu ruang vektor atas lapangan, Hal ini akan di lihat dari sifat ruang vektor atas lapangan, sifat modul bebas.

\section{Grup}

Menurut Setiawan.( 2011), suatu grup $\langle G, *\rangle$ terdiri dari himpunan anggota $G$ bersama dengan operasi biner * yang didefinisikan pada $G$ dan memenuhi sifatsifat berikut :

1. Sifat tertutup : $a * b \in G, \forall a, b \in G$,

2. Sifat assosiatif : $(a * b) * c=a *$ $(b * c) \forall a, b, c \in G$, 
3. Sifat identitas : terdapat $e \in G$ sehingga $e^{*} x=x * e=x, \forall x \in G$,

4. Sifat invers : $\forall a \in G$, terdapat $a^{\prime} \in G$ sehingga $a * a^{\prime}=a^{\prime} * a=e$.

\section{Grup komutatif}

Suatu grup G disebut grup komutatif atau abelian jika terdapat operasi biner komutatif. (Fraleigh, 2003)

\section{Ring}

Menurut Dummit, et al., (1991) $R$ adalah himpunan tak kosong dengan dua operasi biner $(+)$ dan $(\cdot)$, dan memenuhi syarat syarat sebagai berikut :

1. $\langle R,+\rangle$ adalah grup abelian

2. Operasi $(\cdot)$ bersifat assosiatif $:(a \cdot b)$. $c=a \cdot(b \cdot c), \forall a, b, c \in R$

3. Operasi $(\cdot)$ bersifat distributif terhadap (+) di $R: \forall a, b, c \in R$

$a \cdot(b+c)=(a \cdot b)+(a \cdot c)$ (distributif kiri)

$(a+b) \cdot c=(a \cdot c)+(b \cdot c)$. (distributif kanan)

\section{Ring Komutatif}

Misalkan $R$ suatu sistem matematika dengan operasi tambah dan kali. Sistem $R$ disebut ring komutatif jika ring $R$ dan untuk setiap $a, b \in R$ berlaku $a \cdot b=b \cdot a$. (Mardiani, 2016).

\section{Lapangan}

Misalkan $R$ sutau sistem matematika dengan operasi tambah dan kali. Sistem $R$ disebut lapangan jika $R$ membentuk ring komutatif dan setiap unsur tak nolnya merupakan unit, yaitu untuk setiap $a \in R$ dengan $a \neq 0$ terdapat $b \in R \quad$ sehingga $a b=b a=1$. (Mardiani, 2016).

\section{Modul}

Menurut Wijayanti dan Wahyuni (2013), Sifat - sifat yang membentuk modul sebagai berikut :

1. Grup abelian $(M,+)$

2. Operasi $\quad{ }^{\circ}: R \times M \rightarrow M \quad$,dimana $r m$, untuk setiap $r \in R$ dan $m \in M$ yang memenuhi :

a. Distributif kanan

$(r+s) m=r m+s m \forall r, s \in R, m \in M$

b. Distributif kiri

$r(m+n)=r m+r n, \forall r \in R, m . n \in M$

c. Asosiatif

$(r s) m=r(s m) \forall r, s \in R, m \in M$
Jika $R$ mempunya unsur identias 1 maka

d. $1 m=m, \forall m \in M$

\section{Modul bebas}

Misalkan $M$ adalah $R$-modul. Jika terdapat $X \subseteq M$ dengan $X$ merupakan basis untuk $M$, maka $M$ disebut modul bebas.(Khusnul, 2015)

\section{METODE PENELITIAN}

\section{Waktu dan Tempat}

Penelitian ini dilakukan di Fakultas Matematika dan Ilmu Pengetahuan Alam Universitas Sam Ratulangi. Waktu pelaksanaan penelitian ini di mulai pada bulan Mei sampai pada bulan Juni 2018.

\section{Metode}

Metode yang digunakan dalam penelitian ini adalah dengan melakukan sumber literature dengan tahapan sebagai berikut ;

1. Mempelajari sifat ruang vektor atas lapangan.

2. Mempelajari sifat modul bebas

3. Membuat contoh ruang vektor atas lapangan yang terdapat modul bebas

4. Membuat contoh modul bebas yang terdapat ruang vektor atas lapangan

\section{HASIL DAN PEMBAHASAN}

\section{Sifat-sifat ruang vektor atas lapangan}

\section{Teorema 1 :}

Misalkan suatu ruang vektor atas lapangan $F$, dan $X$ suatu subhimpunan dari $V$ yang merentang. Maka pernyataan berikut ekuivalen.

1) Penulisan vektor $y \in V \quad$ sebagai kombinasi linier dari $X$ bersifat tunggal.

2) Penulisan vektor nol sebagai kombinasi linier dari $X$ bersifat tunggal.

\section{Sifat 1 :}

Misalkan $V$ suatu ruang vektor atas lapangan $F$, dan $K$ suatu subhimpunan dari $V$ yang tak kosong. Maka $K$ membentuk subruang dari $V$ jika dan hanya jika

1) Untuk setiap $x$ dan $y$ di $K$, berlaku $x+$ $y \in K$, 
2) Untuk setiap $x \in K$ dan $\in F$, berlaku $a x \in K$.

\section{Sifat 2 :}

Misalkan $V$ suatu ruang vektor atas lapangan $F$, dan $K$ subhimpunan dari $V$ yang tak kosong. Maka $K$ membentuk subruang jika dan hanya jika setiap kombinasi linier vektor di $K$ juga termuat di $K$.

\section{Sifat-sifat modul bebas}

\section{Teorema 2 :}

Misalkan $M$ suatu $R$ - modul, dan $X$ suatu subhimpunan tak kosong dari $M$. Maka pernyataan berikut ekuivalen.

1) $X$ suatu basis modul $M$

2) $X$ membangun modul $M$ dan bebas linier.

\section{Teorema 3 :}

Misalkan $M$ dan $F$ adalah $R$-modul. Jika $M$ adalah modul bebas dan $M$ isomorfik dengan $F$, maka $F$ adalah modul bebas.

\section{Teorema 4 :}

Misalkan $M$ adalah $R$-modul. Jika $M$ adalah modul bebas maka $M$ isomorfik dengan $R^{n}$, dimana $n$ adalah kardinalitas dari basis $M$.

\section{Ruang vektor atas lapangan adala modul bebas}

\section{Teorema 5 :}

Misalkan $S$ subhimpunan tak kosong dari $R$ - modul $M$. Himpunan $S$ dikatakan submodul dari $M$ jika dan hanya jika $S$ tertutup terhadap kombinasi linier sebagai berikut jika $r, s \in R$ dan $u, v \in S$ maka $r u+$ $s v \in S$.

\section{Teorema 6 :}

Misalkan $M$ suatu $R-$ modul, $B$ subhimpunan dari $M$ adalah basis bagi $M$ jika dan hanya jika untuk setiap $v \in M, v$ merupakan kombinasi linier dari vektor vektor di $B$ secara tunggal.

\section{Teorema 7 :}

Misalkan $M$ suatu $R$ - modul. Jika $B$ basis $M$ maka $B$ merentang minimal dan $B$ bebas linier maksimal.

\section{Counter Example (tidak semua modul adalah ruang vektor atas lapangan)}

Modul yang tidak memiliki basis yaitu disebut dengan modul yang tidak bebas. Berikut diberikan beberapa contoh tidak semua modul adalah ruang vektor atas lapangan.

\section{Contoh 1 :}

$\mathbb{Z}_{2}=Z$-modul tidak memiliki basis atau $\mathbb{Z}_{2}$ $=Z-$ modul bukan modul bebas .

\section{Bukti :}

Satu - satunya pembangun yang ada di $\mathbb{Z}_{2}$, yaitu $\{1\}$ yang tak bebas linier, karena terdapat $2 \in \mathbb{Z}$ dimana $2 \neq 0$, sehingga berlaku $2 \cdot 1=0$ di $\mathbb{Z}_{2}$. Oleh karena itu $\mathbb{Z}_{2}$ tak memiliki basis.

Jadi,terbukti bahwa $\mathbb{Z}_{2}=$ Z-modul bukan modul bebas.

\section{Contoh 2 :}

$\mathbb{Z}_{10}=Z$ - modul tidak memiliki basis atau $\mathbb{Z}_{10}=Z$-modul bukan modul bebas .

\section{Bukti :}

$\mathbb{Z}_{10}$ mempunyai satu - satunya pembangun yaitu $\{1\}$ yang tak bebas linier, dimana terdapat $10 \in \mathbb{Z}$ dan $10 \neq 0$, sehingga berlaku $10 \cdot 1=0$ di $\mathbb{Z}_{10}$. Oleh sebab itu, $\mathbb{Z}_{10}$ tidak mempunyai basis.

Jadi,terbukti bahwa $\mathbb{Z}_{10}=$ Z-modul bukan modul bebas.

\section{Contoh 3 :}

Buktikan $\quad \mathbb{Q}=Z-$ Modul dimana $\mathbb{Q}$ : bilangan rasional, $\mathbb{Q}$ bukan merupakan basis dari modul !

\section{Bukti :}

Misalkan $\mathbb{Q}=Z-$ Modul. Akan dibuktikan $\mathbb{Q}$ tidak memiliki basis atau akan ditunjukan bahwa, untuk setiap himpunan bagian dari $\mathbb{Q}$ bukan merupakan basis dari Modul.

Jadi $\mathbb{Q}=Z-$ Modul tidak mempunyai basis $\Leftrightarrow$

Untuk setiap $x \subseteq M$

a) $\quad x$ tidak bebas

b) $\quad x$ tidak merentang

Misalkan $x$ sebarang himpunan bagian dari $\mathbb{Q}$

a) Akan ditunjukan $x$ bukan basis dari $\mathbb{Q}$ :

i) Misalkan $x=\mathbb{Q}$ maka $\langle x\rangle=\langle\mathbb{Q}\rangle$ sub modul terkecil yang memuat $\mathbb{Q}$.

Berdasarkan definisi submodul terkecil merupakan modul yang dibangun oleh satu unsur. 
Karena $\langle N\rangle=\{0\} \neq \mathbb{Q}$ maka $x$ bukan basis dari $\mathbb{Q}$.

ii) Misalkan $x=\{0\}$. Karena terdapat $1 \in \mathbb{Z}$ dan $1 \cdot 0=0$ maka jelas $x=$ $\{0\}$ tidak bebas linier dari $\mathbb{Q}$. Jadi, $x$ bukan basis dari $\mathbb{Q}$.

i) Misalkan $x \neq\{0\}$, sebut $x=\left\{\frac{p}{q}\right\}$ dengan $p \neq 0$ dibentuk persamaan $n$. $\frac{p}{q}=0$ dengan $n \in \mathbb{Z}$.

Jadi $n \cdot \frac{p}{q}=\frac{n \cdot p}{q}=0$ yang berakibat $n \cdot p=0$ karena $p \neq 0$ dan $\mathbb{Z}$ daerah integral maka $n=0$. Jadi $x$ bebas linier di $\mathbb{Q}$.

b) Akan ditunjukan $x$ tidak membangun $\mathbb{Q}$ Yaitu akan ditunjukan terdapat $r=\frac{s}{t} \in \mathbb{Q}$ sedemikian sehingga $r \neq n \cdot \frac{p}{q}$ dengan $n \in \mathbb{Z}$. Akan dilihat beberapa kasus $p$ dan $q$

i) Untuk $p=q$ $x=\left\{\frac{p}{q}\right\}$, maka $x=\{1\}$, ambil $r \in \mathbb{Q}$, yaitu $\frac{1}{3} \in \mathbb{Q}$

$\frac{1}{3} \neq n \cdot \frac{p}{q}$ sehingga $\frac{1}{3} \neq n \cdot 1$, sedangkan $\frac{1}{3}=$ $\frac{1}{3} \cdot 1 ; \quad \frac{1}{3} \notin \mathbb{Z}$ maka $x=\{1\}$ tidak membangun di $\mathbb{Q}$ Jadi, $x$ bukan basis .

ii) Untuk $p \neq q$

1) Andaikan $q=-p$, maka $x=\{-1\}$

Karena $\frac{1}{3} \in \mathbb{Q}$, maka $\frac{1}{3} \neq n \cdot(-1)$, untuk setiap $n \in \mathbb{Z}$

$\frac{1}{3}=\left(-\frac{1}{3}\right) \cdot(-1) ;\left(-\frac{1}{3}\right) \notin \mathbb{Z}$, maka $x=$ $\{-1\}$ tidak membangun

Jadi, $x=\{-1\}$ bukan basis

2) Andaikan $p>q$

Jika $q=1$, maka $x=\{p\}$

Pilih $\frac{1}{3} \in \mathbb{Q}$ sehingga $\frac{1}{3} \neq n \cdot \frac{p}{q}$

$\frac{1}{3}=n \cdot p ; \frac{1}{3}=\frac{1}{3 p} \cdot p, \frac{1}{3 p} \notin \mathbb{Z}$

maka $x=\{p\}$ tidak membangun

3) Andaikan $q>p$;

a. Jika $q \mid n$, pilih $\frac{1}{5} \in \mathbb{Q}$, sehingga $\frac{1}{3} \neq$ $n \cdot x=n \cdot \frac{p}{q} \in \mathbb{Z}$

b. Jika $q \nmid n$, pilih 5 , sehingga $5 \neq n$. $x=n \cdot \frac{p}{q} \notin \mathbb{Z}$

Terbukti, dapat dilihat dari (a) dan (b) maka $\mathbb{Q}=Z-$ modul tidak bebas linier dan merentang. Jadi, $\mathbb{Q}=Z-$ modul bukan modul bebas.

\section{KESIMPULAN DAN SARAN}

\section{Kesimpulan}

Ruang vektor atas lapangan mempunyai sifat bebas linier dan merentang . Ruang vektor atas lapangan yang mempunyai basis disebut modul bebas. Suatu modul dikatakan modul bebas jika suatu himpunan tak kosong $X$ dari modul $M$ memiliki sifatsifat basis yaitu bebas linier dan membangun. Semua ruang vektor atas lapangan adalah modul bebas tetapi tidak semua modul adalah ruang vektor atas lapangan.

Beberapa counter example yang membuktikan bahwa tidak semua modul adalah ruang vektor atas lapangan yaitu $\mathbb{Z}_{2}=Z-$ modul $\quad, \quad \mathbb{Z}_{10}=Z-$ modul dan $\mathbb{Q}=Z-$ modul.

\section{Saran}

Untuk penelitian selanjutnya dapat mencari lagi counter example lainnya yang dapat membuktikan tidak semua modul adalah ruang vektor atas lapangan.

\section{DAFTAR PUSTAKA}

Dummit, et. al. 1991. Abstract Algebra. Prentice-Hall International. New York.

Fraleigh, J. B. 200. A First Course In Abstract Algebra, $7^{\text {th }}$ edition. Addison Welsey. New York.

Khusnul, A. 2015. Keterkaitan antara modul bebas dengan modul dilihat dari sifatsifat homomorfisma modul. Malang : Universitas Islam Negeri Maulana Malik Ibrahim.

Mardiani, D. 2016. Modul dan keujudan basis pada modul bebas. Jurnal Pendidikan Matematika STKIP Garut 5(3): 195-203.

Setiawan, A. 2011. Aljabar Absrtak Teori Grup Dan Teori Ring. Salatiga: Universitas Kristen Satya Wacana.

Wijayanti, I. E dan S. Wahyuni. 2013. Teori Modul. Universitas Gadjah Mada. Yogyakarta. 